\title{
THE EMERGENCE OF INSTITUTIONALISED SOCIAL DIALOGUE IN SOUTH AFRICA
}

\author{
RAYMOND PARSONS
}

\begin{abstract}
This paper looks at the conceptual framework of social dialogue, investment in social capital and some international definitions of social dialogue as background to developments in this sphere in South Africa. Social dialogue is viewed as a mechanism for problem-solving and reducing transaction costs. The paper considers the ramifications of the 1979 Wiehahn Report on labour relations, as well as the nature of social dialogue in the apartheid era and its workplace origins. Institutionally, the stepping stones to the emergence of the NEF and Nedlac are discussed, together with some of the issues involved in, and formal outcomes of, Nedlac over the past eleven years in public policy choices. It closes with an evaluation of institutionalised social dialogue in South Africa and its future.

Keywords: social dialogue; social capital; workplace apartheid; negotiation; NEF; Nedlac; consensusbuilding; public policy choices

"With the transition to non-racial democracy in 1994, it became the task of an ANC-led government to attempt to resolve the economic contradictions that apartheid had created. To achieve this requires massive economic and social changes, great programmes of investment and structural change. It is necessary to create the vital human capital needed at every level, from rudimentary literacy to the highest ranks of science and technology; to overcome enormous deficiencies in all forms of social infrastructure, including housing, schools, health, and transport; to return land to the black population and restore ravaged rural areas; to expand black ownership of mining, industry, commerce, and finance; and to diminish enormous inequalities in income and wealth. The new regime has made a promising start, but South Africa's past will exert a powerful influence on its present and future for a long time to come, and these huge tasks will not be swiftly or easily accomplished." Charles Feinstein (2005)
\end{abstract}

\section{INTRODUCTION}

The subject of my address is the emergence of institutionalised social dialogue in South Africa especially as eventually embodied in the National Economic Development and Labour Council Nedlac. It will not be lost on you that there are significant commonalities between the obliging provider of today's fine venue and the principal subject of this address: Nedlac, like the Reserve Bank, has a statutory existence (albeit, in Nedlac's case, not one that is also reflected in the Constitution), whilst both national institutions are charged with important responsibilities with regard to the good health and efficient functioning of South Africa's economy.

The social dialogue process has been a part of South African public life for several years, yet its role has not yet been adequately noted or evaluated. It occurred to me that 
perhaps some good purpose may be served by reflection on the subject, which may well encourage deeper academic scrutiny of the development of institutionalised social dialogue - and investment in social capital - in this country In other words: What has happened? How did it happen? And why did it happen?

'History, it is often said, 'is lived forward but is written in retrospect. We know the end before the beginning and we can never wholly recapture what it was to know the beginning only. This analysis therefore seeks to describe the political and economic setting in which the origins of South African social dialogue and Nedlac are to be found. Ideas tend to take root when the soil has been fertilised by social and economic trends -and in South Africa's case, by political developments as well. This helps to explain both the emergence of 'institutionalised social dialogue' in this country — and also the extent to which that had its roots in workplace issues.

First of all, though, what do we mean by 'social dialogue'? The concept is an elusive but pervasive one. Globally it sails under a number of flags. These include 'social capital', 'civil society, 'civil engagement', 'tripartism', and even 'corporatism'. A growing body of literature has accumulated around these separate but related concepts, especially since the end of the Cold War. For many economists the term 'social capital', like its conceptual relations, remains an imprecise concept whose role in economic development is no less hard to pin down. ${ }^{1}$ Social dialogue is apt to mean different things to different people.

Yet it exists. Globally about 50 countries now have similar structures to Nedlac and the list is steadily expanding. On all sides there are strong reasons why the language of'social dialogue' appeals and suggest an interesting interplay between politics, economics, and ideas. With the recent surge in academic literature on social capital it is worthwhile to give more thought to what social capital is, what we have learnt from existing studies, and what issues need to be further explored, especially in the South African context. It would be a rewarding study in the art of political economy.

An encompassing working definition of institutional social dialogue was given by the International Labour Organisation (ILO) in 1996 as follows:-

All types of negotiation, consultation or simply exchange of information between, or among, representatives of governments, employers and workers, on issues of common interest relating to economic and social policy. It can exist as a tripartite process, with the Government as an official party to the dialogue or it may consist of bipartite relations only between labour and management (or trade unions and employer associations), with or without indirect government involvement. Concertation can be informal or institutionalised, and often it is a combination of the two. It can take place at national, regional or at enterprise level. It can be inter-professional, sectoral, or a combination of all of these.'

The ILO has gone on to say that 'the main goal of social dialogue itself is to promote consensusbuilding and democratic involvement among the main stakeholders in the

\footnotetext{
${ }^{1}$ We know some of the factors that are good for growth: high investment rates, high savings rates, reliance on market mechanisms, and openness of the economy to both trade and investment flows, and investment in human capital all help. But there are many others of which our understanding is anecdotal or nascent at best, though they appear suggestively important. Institutions, values, ethics, culture all float about in these reaches, though present' — Fedderke, Johannes, 'So Weber was right all along', Theoria, 93, June 1999, p. 4.
} 
world of work'. This implies that social dialogue is now more generally viewed characteristically and historically — as tripartite in more inclusive terms. Yet we must accept that there are still conceptual and other difficulties around the issue of social dialogue which are as yet unresolved.

This has probably been one of the main reasons why the debate around social dialogue in South Africa has often been at cross-purposes. Yet any measurement or evaluation of the impact of social dialogue depends on how the concept itself is understood, and therefore on what is expected of its associated processes and systems in general. As we have no unequivocal measure of economic development, no clear-cut analytical framework exists which links national institutions and overall performance. Given that development studies in recent years have acquired new dimensions, it is even unlikely that there is only one formula for 'social dialogue-in-democracy', thus leaving scope for different interpretations of its potential role.

Yet while there are difficulties about definitions of'social capital' and 'social dialogue', they are by no means fatal to the usefulness of the concept. The economists' idealised model of'social dialogue' is probably best embodied in the concept of'social capital'. This phrase hints at the pleasingly communal, but also incorporates a rigorous element of hard economics. For the bulk of this exposition I will later nonetheless use the term 'social dialogue' as a proxy for 'social capital', given the common usage. But what is 'social capital'?

It is broadly defined as the ability of people to work together in their enlightened selfinterest for common purposes in groups and organisations. Social capital identifies the conditions in which individuals can utilise their participation in groups and networks to obtain benefits. As a concept it takes its place - though not yet fully - alongside the familiar definitions of financial capital, physical capital, human capital and intellectual capital. 'Social capital' is to some extent merely new language for a very old debate about how cooperative networks can make a society more productive. ${ }^{2}$ Social capital is desirable because it is perceived to be associated with good economic performance.

Economists believe that a society which embodies generalised reciprocity is more efficient than a distrustful society, in the same sense that money is more efficient than barter. It thereby lowers transaction costs. Where transaction costs exist, institutions matter. Trust hinges on the institutional environment. Professor Fukuyama says that 'a nation's well-being, as well as its ability to compete, is conditioned by a simple cultural characteristic -the level of trust in a society'. ${ }^{3}$ Trust therefore has an economic value to a society.

In low-trust societies what happens is that there is:

- formal cooperation only

- a highly rigid system of rules and regulations

- a legal apparatus serving as a substitute for trust

In other words, a low-trust society imposes a type of tax on all forms of economic activity, apart from its potential threat to social stability in a 'worst case' scenario. ${ }^{4}$

\footnotetext{
2 'A well-connected individual in a poorly connected society is not as productive as a wellconnected individual in a well-connected society'. Robert D. Putman, Bowling Alone, New York, 2000, p. 20.

3 Fukuyama, Francis, 1995, Trust: The Social Virtues and the Creation of Prosperity, London, p. 23.

4 We nonetheless should not assume that all social capital has benign outcomes. Social capital can be dedicated to negative or malign purposes, just like any other type of capital.
} 
Social capital can, of course, be depleted and renewed over time. The system of apartheid, by fracturing South African society horizontally and vertically, reduced its investment in 'social capital' substantially It left a widespread legacy of mistrust and suspicion. The sense of 'give-and-take', of compromise, of consensus-seeking, all these needed to be rediscovered in the post-apartheid era. It has been necessary to create institutions and structures which could rebuild trust in a deeply divided society.

It has been important to examine how the positive consequences of 'social capital' -mutual support, cooperation, trust, institutional effectiveness - can again be maximised in South African circumstances. It is in reality an established recipe which has not lost its relevance to this country ${ }^{5}$ We must, nonetheless, bear in mind that, in focusing mainly on the eventual role of Nedlac, we are dealing with but one key aspect of the phenomenon we are addressing.

We should therefore recall that, ever since it was launched on 18 February 1995, Nedlac has often been the subject of controversy, some critics having expressed the view that it would fail to achieve the goals set for it at its inception. There was understandably considerable scepticism in some quarters. In spite of this, by 2005 over 120 agreements had been reached by Nedlac on a wide range of economic and social policy issues, and numerous reports and other activities had been completed.

More important, however, is whether the existence of Nedlac — and the many hours spent in discussion and negotiation by the participants - have served to raise the level of trust and understanding — especially between business, labour and government — to a point that such essentially social gains will have made for greater unity of purpose, more effective policymaking and speedier policy implementation. If so, then Nedlac could well be regarded as an important investment in 'social capital' contributing over time to the emergence of a 'high trust' society fully comparable with 'healthy', prosperous, competitive societies in other parts of the world. So what is the balance sheet here?

To assess and understand Nedlac's establishment and its role in what remained of the $20^{\text {th }}$ century — and subsequently — it is first of all necessary to refer to some prior developments leading up to its creation. We must locate our historical bearings. It will be recalled that 1990 was the crucial year in which the future President Nelson Mandela was released from prison, unleashing the various political and social forces which ultimately culminated in a negotiated full democracy in 1994 and with that the end of the apartheid system in South Africa. To that extent at least the advent of representative democracy and development of institutionalised social dialogue must be said to have converged in South Africa.

\section{STEPPING-STONES TO NEDLAC}

To begin, then, with historical notions and origins.

Although Nedlac eventually arose from a merger of the National Economic Forum (NEF) and the National Manpower Commission (NMC), the genesis of tripartism in South Africa can be traced back to the labour relations arena which developed in the wake

\footnotetext{
' 'We have found an unfailing remedy for racial disharmonies - we get people to work together at a common task: the task takes over and new illumination lightens up the scene' - S. Herbert Frankel, The Economic Impact of Under-developed Societies, Oxford, 1959, p. 179.
} 
of the watershed Wiehahn Commission report in this area in $1979-{ }^{6}$ The acceptance of most of the recommendations of the Wiehahn Commission by the National Party Government of the day was significant, because it paved the way for the legitimising of black and multiracial trade unions in South Africa, and their subsequent recognition by commerce and industry It was a major step forward at the time to normalise labour relations in this country.

We should not, at this remove, underestimate the impact which the Wiehahn Report made on the political and socio-economic circumstances then prevailing:-

'The recommendations of the Wiehahn Commission — appointed in 1977 — produced a veritable watershed in labour relations in South Africa. It was unique in its consequences. It constituted the first crack in the wall of apartheid. After Wiehahn nothing would ever be the same again ... no other official enquiry had as incisive an effect on the South African economy as the Wiehahn report has had. An independent study found that more than eighty percent of the recommendations had been positively reacted upon by the Government'.

In this process, the power relations within the South African economy started to shift from a highly paternalistic framework - which essentially had government deciding what was best for the country, and employers deciding what was best for their workers -towards a more inclusive and consensual framework of decision-making. This shift predated, but would in many respects be seen to have been synchronised with, South Africa's gradual movement towards a democracy that would place value on, and give full recognition to, human rights.

The experience gained by both organised business and organised labour in the postWiehahn industrial relations system — such as through the National Manpower Commission (NMC) - equipped individuals within each of these constituencies with the necessary tools to act as facilitators, mediators and negotiators, and in doing so made a more collaborative decision-making process possible. Although South Africa had officially withdrawn from the ILO in 1967, informal links with that body were maintained by some stakeholders — and these were also of assistance in this period.

However, that is not to deny nor make light of severe tensions between the parties in the post-1980 period - especially since the apartheid system had created a political vacuum which the new trade union movements understandably attempted to fill. This resulted in some, if not all, major unions assuming political roles which extended far beyond the general framework of an inclusive collective bargaining system.

As these activities increased, so leaders in organised business realised that commerce and industry would continue to bear the brunt of these pressures unless there was meaningful political reform. As a consequence of this, calls for a political settlement from the organised business community grew more insistent and there were increased attempts to promote a broadly-based commitment to fundamental human rights in South Africa.

This private sector initiative probably contributed to the exclusion of organised business from a restructured Economic Advisory Council in 1986 by then President PW Botha, but it may have helped to improve the business lobby's credibility with the trade union movement. This may also have been assisted by the opposition of organisations

6 Republic of South Africa, Report of the commission of inquiry into labour legislation, RP47/1979.

7 Botha, J. -Wiehahn, N. E. (1929-2006), Obituary- South African Journal of Economics, June 2006, pp. 359-361. 
such as the Association of Chambers of Commerce (ASSOCOM) and the Federated Chamber of Industries (FCI) to the use of detention without trial against trade union leaders at the time.

It might therefore be argued that, in spite of the mounting exogenous pressure on the industrial relations system during the latter half of the 1980s, significant pathways of trust were slowly emerging between the different constituencies. Unfortunately, much of this trust developed between individual personalities involved in the industrial relations process rather than at an institutional level — so that then as now, the consensus-building exercise was subject to the vagaries of leadership moving into different spheres of activity.

By 1988 the then government tried to 'roll back' some of the advances made since the Wiehahn report. Pressure from both organised labour and organised business resulted in an historic agreement being reached in 1990 which was subsequently endorsed by the Cabinet and signed by the then Minister of Manpower. Apart from providing the foundations for a new Labour Relations Act, the important 'Laboria Minute' — as the Agreement came to be known - also made provision for the formation of an appropriate forum to discuss the impact of labour relations on the economy. However, the trade unions interpreted this provision more widely, arguing that the forum should discuss, and even negotiate, all micro and macro economic policy issues.

At the time there was a great deal of scepticism within the business sector about the motivation of the unions for such an interpretation. Some business people argued that the unions and their political allies merely wanted to use the forum to put additional pressure on the Government of the day. Others again saw it as a 'ploy' on the part of organised labour to set their ideological 'battle' with business in a more rigid framework, one that would ultimately land business in positions which it would not otherwise have countenanced.

Although many business people were in any case strongly convinced that political change was essential, as the negotiations over a new political dispensation developed - and it became clearer that the African National Congress (ANC) and its allies would assume the dominant role in any future government - so concern grew within business over the extent of the ideological 'divide', the kind of economic policies that might be adopted, and its own ability to influence future policy-makers. The rising use of strikes and boycotts by the unions was also hurting the economy and business. There was clearly a growing need to move away from a dominant culture of 'adversarialism' in the socio-economic arena towards one of consultation and dialogue - and perhaps even one of forging agreements.

\section{EMERGENCE OF THE NATIONAL ECONOMIC FORUM (NEF) AND NEDLAC}

Against this backdrop, both organised business and organised labour began to see advantages in a negotiating forum for constructive engagement. The then Consultative Business Movement $(\mathrm{CBM})^{8}$ also played an important role in facilitating this process. As a result, a series of meetings between labour and business occurred and agreement was reached about a forum to discuss economic issues. The next step was to get a hesitant government on board in the early 1990s.

\footnotetext{
${ }^{8}$ A business grouping specifically dedicated to promoting socio-economic change.
} 
Ongoing trade union hostility at the time to the introduction of value added tax on a wide range of'basic' foodstuffs, which were previously exempt from general sales tax, and the firm opposing stance adopted by the then Finance Minister - Barend du Plessis -contributed to the reluctance on the part of government to join the forum process. However, when du Plessis resigned in April 1992 and was replaced as Minister of Finance by Derek Keys (who came from the business community), this obstacle to government's participation was removed.

Following a 'summit' meeting between Keys and a joint business-labour delegation, the Cabinet agreed to the formation of the NEF The founding documents were soon drafted and the NEF was established administratively Keys referred at the time to the 'golden triangle' of government, labour and business. Both Keys and Alec Erwin (then a senior economic spokesperson for the African National Congress/South African Communist Party/Congress of South African Trade Unions (ANC-SACP-COSATU) alliance, subsequently a cabinet minister in the Mandela and Mbeki-led governments) played important roles in the establishment of the NEF.

The NEF was an informal structure set up with two working groups - one of which focused on the short-term issues, whilst the other was to have dealt with longer-term policy matters. However, because of the changing power relations in the country at the time, and the inability of the then government to address long-term policy matters, the focus of the NEF's activities was to be very much on short-term issues affecting day-today economic governance. There was little success in developing a common 'vision' for South Africa's economy. But by keeping the economic policy 'wheels' turning, and by diverting political agendas away from the shop floor, the NEF played a highly constructive role in the country's transformation at that stage.

Several participants believed that the NEF's strength at the time lay in its informality. The creation of the NEF in 1992 had been seen as the result of a needs-driven voluntary process mainly initiated in its early stages by labour and business, reflecting a political will to make it work and deliver. It was not a statutory body, yet bound its key players to important agreements. The role of informal discussions, the combination of constituency mobilisation (sometimes in the form of strikes) and tough bargaining at the NEF, created the platform on which the future social dialogue framework would be built.

In addition, the NEF provided the various constituencies with some understanding of the perspectives and problems of the other participants, and helped to develop some capacities amongst them. Although labour was very good in the areas of process and negotiation, it had as yet little understanding of the implications of proposed policies, whilst in the case of government, certainly in conditions prevailing in the 1990s, the reverse was closer to being true. Somewhere between the capacities of labour and government stood business - with some individuals having experience of processes and negotiations, and others with a clear understanding of policy implications. The trick lay in combining these skills and fortunately some of the constituency leaders were able to meet this challenge in order to further social dialogue.

Most obvious of all, but no less significant for that, the mere process of establishing or improving cross-cultural human relationships must have done something — and perhaps did quite a bit - to facilitate the formation of social capital at a crucial stage. If so, a large part of its genesis lay in workplace changes. There was also significant personal 'chemistry among the key participants which, in a sense, carried itself through to the eventual 
establishment of Nedlac. The transitional NEF was a good apprenticeship for the more formalised Nedlac that still lay ahead.

At roughly the same time as the NEF was established the NMC was restructured, with commissioners being selected on the basis of representativeness, rather than expertise - as had previously been the case. Whilst the focus of attention of the NMC continued to be on the labour market and the labour relations system, it also became an embryonic tripartite negotiating structure along similar lines to the NEF.

Another source of renewed cooperation and trust-building lay in addressing the endemic political violence which characterised the early 1990s and which threatened to derail the political negotiation process. Apart from the start of trilateral engagement around workplace challenges, critical developments were also unfolding on a broader political level which began to involve other formations such as organised labour and business in the National Peace Accord. The negotiated National Peace Accord was an important mechanism for keeping contemporary political violence to manageable proportions, and involving more or less the same 'actors' as were participating in the NEF. They were all linked to a greater or lesser extent to the tough and tumultuous political process then underway.

After the 1994 elections and with the formation of the Government of National Unity (GNU), many of the labour participants in the NEF moved into senior policy-making positions within government, and carried with them a generally favourable view of tripartism. Against this, there were from a business perspective still some concerns and uncertainties about the future direction of economic policy, and even then talk of an inevitable 'rift' developing between the ANC and its trade union allies. Advocates of the market economy were concerned that its future appeared to rest on fragile political foundations.

On all sides it was also recognised that deep unresolved difference of opinion as between the three participants remained an obstacle to the development of the national 'vision'. This goal was perceived to be essential to both national reconciliation and the realisation of South Africa's economic potential — and as a means of countering the negativity of sceptics abroad. The gains to be had from compromise therefore continued to look attractive.

As a result, there were elements within all three constituencies - but particularly in labour and business - that were favourably disposed to the formalisation of the NEF process. In this period several informal processes would have significant formal consequences. Soon after the elections in 1994 business and labour met with a number of cabinet ministers in the new government seeking to formalise the structures of institutionalised social dialogue. Events then moved to the drafting of the Nedlac legislation.

The process leading up to the launch of Nedlac was characterised by robust and intensive negotiations. On all sides, however, there was a real commitment to make Nedlac work spurring a group of constituency leaders to advocate a social dialogue structure which could help in addressing South Africa's serious socio-economic challenges. This included the challenge of transforming the economy from one that had become inward-looking, uncompetitive, excessively protected and isolated from the world economy into one which would be open, competitive and growing — no less, in other words, than to reintegrate South Africa into the international economy and the globalisation process in the post-sanctions era.

Given that both the NEF and the NMC had effectively developed along tripartite lines representing the same constituencies, it was logical for any new structure to incorporate 
the two bodies. Discussions in the latter half of 1994 centred on how this could best be done. Nedlac was then established as a statutory body with its structure, operational powers and characteristics being prescribed in the Nedlac Act No. 35 of 1994. The Nedlac Act was one of the first pieces of legislation passed by the new Parliament.

In summary therefore, it could be said that the four main stepping stones to the creation of Nedlac were the Wiehahn Report, the NMC, the Laboria Minute and finally the NEE When the economic history of this period comes to be written, special recognition must be given to the significant and decisive role played by the NEF at the time. It proved to be a distinctly important institutional bridge between the 'old' and the 'new' regimes and in the building of social capital in South Africa.

\section{LAUNCH OF NEDLAC}

Nedlac then came into being on 18 February 1995- High expectations and enthusiasm in many quarters surrounded the launch of this institution. Nedlac was to be a major instrument of post-conflict rehabilitation. It was intended to inaugurate a new era of inclusive consensusseeking and ultimately decision-making in the economic and social arenas. The enabling legislation formally spelt out Nedlac's task to pursue the goals of growth, equity and participation. As the legislation indicated, Nedlac had a broad scope of activity covering all aspects of social and economic policy and decision-making.

At its inception in 1995 Nedlac's five objectives - which would shape its agenda - were specifically outlined as follows, namely to:-

(i) Promote economic growth, participation in economic decision-making and social equity

(it) Seek policy to reach consensus and conclude agreements on social and economic policy

(Hi) Consider all proposed labour legislation relating to labour market policy before it was introduced into Parliament

(iv) Consider all significant changes to social and economic policy before it was implemented or introduced into Parliament, and

(v) Promote the formulation of co-ordinated policy on social and economic matters.

From the outset it was acknowledged that for the negotiation process in Nedlac to succeed, first prize would be to secure agreements. To start with it was necessary to develop a work programme that would identify the key issues on which the social partners needed to be seeking agreement. The work programme itself would have to evolve out of a consensus about the socio-economic priorities for South Africa - and would to a large degree be distilled out of the economic agenda of the governing political alliance.

Nedlac therefore drew heavily on the experience of its predecessors - the NEF and the NMC. It also modelled itself to a large extent on successful institutions of social dialogue in other parts of the world, notably Holland and Ireland, but with adaptations to take account of the development challenges of South Africa. ${ }^{9}$ It was also hoped that the formalised process of information sharing at the national level would enable participants

\footnotetext{
${ }^{9}$ Just as we must recognize that there are successful national economies that do not depend on 'institutionalised social dialogue' in the form we are currently discussing — in itself a valuable source of comparative analysis.
} 
to strengthen commitment and build trust. ${ }^{10}$ Social capital provides data which can make further cooperation possible. This collective knowledge could become a valuable asset in decision-making and in finding workable compromises so as to lower transaction costs.

Compromise, of course, did not mean the surrender of one side to the others. All parties had to make some contribution. Up to a point, the agreement might represent a genuine accord which had developed out of conflict or controversy. Short of that point, the contribution made by one or other side within Nedlac would depend, on the whole, upon the respective strengths of the parties and the skill of their negotiators at any given time. It was granted there could be compromises that were weak or difficult to defend. Often social dialogue outcomes could result in policies being those that would secure agreement, rather than those that would achieve a given set of objectives efficiently. This is partly why some critics dislike Nedlac 'compromises'.

Nedlac was, and remains, institutionally distinctive in several ways. It is the most representative policy body South Africa has ever had, since it includes government, labour, business and the 'community'. ${ }^{11}$ It is an agreement-making body of broadly equal partners and not merely an advisory body. Of the about 50 countries, mainly developing ones — which have Nedlac-type institutions - Nedlac is among the very few that is a negotiating body and not only an advisory one.

Nedlac also requires mandated representatives, which means that constituencies are held accountable for the consequences within their sphere of influence. South Africa has therefore developed its own 'hybrid' system of social dialogue through Nedlac — the 'golden triangle' having now become 'quadrilateral' or a 'quadrangle' by including the community constituency at certain levels but not in all the Chambers. There have been special reasons for this particular configuration.

And what was social dialogue intended to do? Institutionalised social dialogue was needed to help undo the damaging legacies of apartheid and address the challenges of economic performance, more especially with reference to growth, job creation and poverty. Pitched at its highest, Nedlac was intended to provide the socio-economic dimension of the reconciliation and nation-building to which President Mandela was strongly committed. The main participants in Nedlac — predominantly the ANC-driven government, business and labour all had their reasons for engaging in the Nedlac process. From their various perspectives they all hoped that, in one way or another, Nedlac would help to keep the country 'governable', and maximise their own influence in the process.

Although Nedlac was regarded at the time as an agreement-making body rather than an advisory one, it was recognised by all participants that the Nedlac process was not supposed to be a substitute for Parliament. Whilst agreements could be reached between the social partners, such agreements were not intended to be binding on the country's elected representatives and certainly could not, in the absence of Parliamentary debate and adoption, result in changes in the laws of the land.

\footnotetext{
10 'It can be plausibly argued that much of the economic backwardness in the world can be explained by a lack of mutual confidence', Arrow, Kenneth J. Gifts and exchanges. Philosophy and Public Affairs, (Summer 1972), p. 357.

1 The 'community' constituency widened participation in social dialogue and to a large extent reflected the constituency with the then biggest stake in the new governments' Reconstruction and Development Programme (RDP). It broadly included women, rural, youth, civic and similar organisations. For some years it was a difficult group from which to derive mandates.
} 
Furthermore - and especially given the contemporaneous political power balance that included a formal alliance between the ANC, COSATU and the SACP - the fact that the parties that were likely to be most affected by proposed legislation had reached agreement on it, was expected to significantly reduce the likelihood of parliamentary opposition to its enactment. That said, problems did soon develop in the relationship between Nedlac and Parliament — the perception that there appeared to be 'two parliaments' - and these difficulties persisted for some years.

In the early years of Nedlac the Government delegations tended to play a dominant role in setting Nedlac's agenda but this has changed over time and the social partners have become more proactive in shaping certain policy choices. Experience soon suggested that the influence of negotiators depended on more than representational status. Technical expertise was important, persuasiveness counted a great deal, diplomacy, a sense of timing and experience in social dialogue mattered - all had an impact. None of these requirements are prescribed anywhere in Nedlac documentation, yet they have proved decisive in securing workable outcomes.

The 'engine rooms' of Nedlac today are its four chambers, in which the social partners discuss issues related to the specific portfolio of each chamber. These are the Labour Market Chamber, the Trade and Industry Chamber, the Public Finance and Monetary Chamber, and the Development Chamber. The community constituency is officially represented only in the Development Chamber.

All in all, the Nedlac arrangement ('tripartism plus') is more inclusive than those of most other similar institutions elsewhere - in other words, social dialogue and civil dialogue are not as compartmentalised as they are, for example, in the European Union (EU). This inclusivity has both advantages and disadvantages for the functioning of Nedlac. It has undoubtedly had an important influence on the policy areas to be covered and in the setting of the Nedlac agenda.

\section{OVERVIEW OF NEDLAC'S FORMAL OUTCOMES ${ }^{12}$}

During its first few years Nedlac's main focus was on negotiating the introduction of government's new labour market policy and legislation. Whilst Nedlac's labour market processes enjoyed a correspondingly high profile, the Trade and Industry Chamber also began to do important work in the spheres of trade liberalisation, preliminary discussions on the formulation of an industrial strategy, and competition law reform. Nedlac's agenda slowly broadened over time to include a range of socio-economic matters.

But labour issues predominated. Soon after the 1994 elections the then Labour Minister Tito Mboweni launched a complete overhaul of the South African labour market. Intentions were spelled out in the Department of Labour's five-year plan and commenced with comprehensive review of the Labour Relations Act (LRA) and the appointment of a Presidential Commission into the Labour Market.

\footnotetext{
12 The developments and trends in the work of Nedlac 1995-2005 are mainly captured in the detailed annual reports which the organization is required by law to submit to parliament each year. Although they tend to put a favourable gloss on Nedlac's activities, they are nonetheless a reliable overview of the institution's work programme. The ten-year review of Nedlac (2005) has also been helpful in recalling events.
} 
Due process required any legislative proposals resulting from either initiative would have had to be referred to Nedlac in due course. However, the proposed far-reaching changes to both the LRA and the Basic Conditions of Employment Act (BCEA) were prematurely rushed into the Nedlac process — the LRA redraft even before the Presidential Commission had been appointed, and the BCEA before the Commission had reported.

The first important issue addressed by Nedlac in 1995 was therefore the draft amending legislation (to revamp the LRA), which threatened to set a pattern. It proved to be a stern test of the fledgling organisation and, by the same token, for future 'quadrilateralism'. Pressure to reach agreement was heightened by the Minister of Labour setting short deadlines for the completion of negotiations. Less than three months were provided for the respective parties to reach consensus, which in the circumstances was rather inadequate. Labour market changes, after all, lay at the crucial intersection of economic, social and political policies and were bound to be a heavily contested terrain requiring careful strategic planning and an integrated approach.

There are two aspects of this early experience in Nedlac that still need to be emphasised:-

First, the policy underlying the LRA was never properly considered by the Presidential Commission, either on its own terms or as part of the labour law reform process as a whole. Reform of the LRA and the BCEA accordingly went ahead without a thorough labour market evaluation - either in respect of their particular subject matters or in respect of the linkages to other aspects of the labour market, such as skills development and social security.

Secondly, the phased nature of the negotiations precluded presentation and negotiation of a single and coherent package of labour reforms. In part these errors and omissions can be attributed to high expectation that a broad social accord was in fact emerging at the time; in part it was doubtless considered that early introduction of meaningful reforms would demonstrate the Government's commitment to protecting workers in any social accord. As we have seen, there had already been a positive history of social dialogue up to then - and hence there was the real expectation of a broader social accord to stabilise and drive the postapartheid economy.

The overall accord never materialised. Accordingly the labour law reform process, albeit always tripartite in composition, was segmented - its different facets being separately introduced and negotiated. Many of the recommendations of the Presidential Commission never saw the light of day. And those that were introduced (such as the amendment to give the Minister of Labour the discretion whether or not to extend sectoral collective agreements) were withdrawn in response to fierce opposition from organised labour. The effect therefore was that the labour law reform process - although necessary — dissolved into piecemeal negotiations, from whence several serious unintended socio-economic consequences emerged in subsequent years.

Another important strategic 'gap' in the early days of Nedlac's operations was the fact that attempts were being made to reach agreement on various issues in the absence of an overall framework for economic policy-making. Similar tensions accompanied other elements of the Ministry of Labour's five-year labour programme — such as the BCEA-even after the release of the Growth, Employment and Redistribution (GEAR) strategy in 1996 which referred to 'a more flexible labour market'.

Initially, government indicated that the basic policy lines of the GEAR strategy were not negotiable, even within Nedlac. This was partly because implementation of the 
strategy was deemed to be urgent, partly because some elements like interest rates, taxes and fiscal deficits were not practically negotiable in any modern economy, and partly, it seems safe to say, because the Government surmised (correctly) that organised labour would strongly oppose GEAR. Whatever the reasons, it did put considerable strain on the Nedlac processes.

The organised labour constituency felt its positions were indeed threatened by several of the policy choices made in the GEAR, which it considered were too market-friendly Union leaders began to use their influence within the ANC-led alliance to re-open negotiations on the strategy ${ }^{13}$ The fact that certain cabinet ministers were known to be ambivalent about the GEAR strategy gave organised labour additional leverage. Comments made by some senior government representatives at COSATU meetings at the time suggested that organised labour had some success in generating equivocal official attitudes about GEAR. It also frustrated the work of the Public Finance and Monetary Policy Chamber in Nedlac for several years. Within Nedlac this chamber became the lightning conductor for opposition to GEAR.

While this has not prevented the development of a problem-solving approach by Nedlac participants to specific policy issues (as outlined in clause V of the 1995 Founding Declaration), the lack of an overall shared vision has from time to time generated considerable tension in Nedlac. Yet a dialogue which becomes problem-solving and practical can produce consensus, even where there are deep underlying conflicts of interest, and even where there may be no shared understanding at the outset. Experience also suggests that adopting that approach to achieve consensus in one sphere often facilitates a similar attitude towards other areas of policy. Nedlac has been both a steep learning curve and a strong intellectual challenge in policymaking.

Hence over the past eleven years Nedlac - as the portal of entry into social dialogue in South Africa - has found itself driven into an ever-widening socio-economic agenda as its processes matured. It has probably become the most complex agenda of any public institution in South Africa. It has had both successes and failures and has undoubtedly also been a source of deep frustration for Nedlac participants from time to time. In practice, it was to become not only an institution in which to reach formal agreements, but was also to evolve into an instrument of consultation and coordination regarding several policy issues. Important events like the Jobs Summit (1998) and the Growth and Development Summit (2003) were also organised under Nedlac's auspices and generated heavy policy as well as project commitments by its stakeholders. The range of activities covered by Nedlac since its establishment is well reflected in its successive Annual Reports.

\section{EVALUATION OF THE ROLE OF NEDLAC}

Any assessment of the Nedlac role since its formation in 1995 would — in part at least -be bound to reflect one's overall perspective on the South African economy, politics and society in these years. ${ }^{14}$ Nedlac and social dialogue over this period undoubtedly attracted

\footnotetext{
Organised labour had thrown its weight behind the Reconstruction and Development Programme (1994) but that document did not embody an economic strategy.

14 Some leading political analysts, on the other hand, seem to offer an assessment of South Africa's political development since 1994 without any reference to Nedlac at all. See, for example, Lodge,
} 
critics; and to give the most strident of those their day in court, the most sweeping of all possible questions must be posed: Would South Africa have been better off without Nedlac?

While much more empirical analysis is clearly needed to evaluate Nedlac's interventions in specific policy matters - and how they may have influenced policy outcomes — the interim and overall qualitative answer must be 'no'. Without the conflict-management potential of a structure like Nedlac, the transition to a successful democracy would have been, to say the least, trickier than it needs did prove to be - especially so within an emerging market like South Africa.

Indeed, it could be argued that the recurring spectacle of labour and capital sitting down together to discuss policy under the auspices of Nedlac was reassuring to investor confidence. It has rightly been emphasised that South Africa has been able, through sound monetary and fiscal policies, to inject more certainty and predictability into the policy environment. Less credit, however, is given to the perception of stability to which institutionalised social dialogue also contributed.

Economies are vulnerable during their transition phases. There are difficult perceptions to handle, in what are often periods of acute uncertainty. We must accept that - in moving from a 'closed' regime to an 'open' one - a country usually has to go through a transitional period that may require its leaders to expend huge amounts of political capital with no guarantee of success. Nedlac has had to help make a difference here. ${ }^{15}$ While Nedlac has not governed the country, it has arguably helped to keep it governable.

Has social dialogue - and investment in social capital - made a quantifiable difference to South Africa's economic performance since 1994? It is extremely difficult to link a specific institution or feature on the national landscape to a particular set of economic results. It is really not possible to establish a direct correlation between extensive peak-level social dialogue and higher economic growth rates, or a rising human development index. All that can safely be said of South Africa is that the average economic growth rate rose from nearly zero in the early 1990s to about 2.5 per cent in the six-year period post-1994 - and that the acceleration of growth in the most recent years is arguably an extremely significant reflection of the groundwork that took place in the earlier period.

To the extent that certain processes, such as Nedlac, promoted social stability and reduced perceived country risk, they must have made a positive contribution. South Africa's international credit ratings (e.g. Moody's, S\&P, Fitch) did slowly begin to improve in the early years and subsequently they have returned increasingly favourable verdicts on the South African economy. These are developments in a period which has been historically designated as a one of 'consensual stability — and to which Nedlac contributed. 'Consensual stability' has helped to reduce uncertainty and raise expected returns on investment.

Overall, it is evident from an analysis of the Nedlac experience over this period that there are certain quite fundamental issues on which the Nedlac constituencies are far apart and where substantial dialogue and negotiation will still be needed to forge greater consensus. However, there have been policy areas - as the agreements already reached and reports issued amply confirm — where there has been a high degree of commonality of

Tom, South African politics since 1994, Cape Town, 1999.

${ }^{15}$ See also The J Curve: a new way to understand why nations rise and fall, Ian Bremmer, Simon and Sehuster, New York, 2006, reviewed in The Economist, 2 September 2006, p. 75. 
interests and views and worth the trouble of placing it on the Nedlac agenda. Nedlac needs to be seen as an opportunity, not a burden. Yet in recent years there has also been a strong view among several participants in Nedlac that the social dialogue process has become unduly protracted and too time-consuming.

We must recognise too that, at times, social partners can, by reason of vested interests or perhaps by too easily conceding to one another's strongly held opinions, be obstacles to change, not promoters of it. Ideally, the safeguards in Nedlac's case are two-fold - firstly, that the government is expected to participate in Nedlac as a watchdog of the broader public interest and secondly, that the constituents in Nedlac, which include the wider community, are unusually broadly-based. But it is necessary to ensure that the Nedlac process is not captured by narrowly-based interests which would damage its credibility. Social dialogue must be seen as a means to an end, not an end in itself

Nonetheless, no institution - no matter how rich its history - may shirk the challenge of taking stock of its role in a changing environment. Both government and other participants in Nedlac believed that, after eleven years, the functioning of Nedlac needed to be reviewed to assess its performance. Some serious institutional and operational challenges had developed and needed to be addressed. For if function declines, so also do status and influence. Nedlac therefore recently commissioned a wide-ranging independent ILO-led audit and evaluation of its role and performance, as well as making recommendations for future Nedlac strategy.

This evaluation will be an important opportunity to reassess the role of institutionalised social dialogue and Nedlac in South Africa. How well has Nedlac done? Where has Nedlac failed and why? What are the boundaries of social dialogue in South Africa? Do we still need Nedlac? Have institutions like Nedlac, in other countries, been tested by differences as deep as those which still exist here? How should Nedlac in future structure its contribution to policy, and is the institution adequately resourced to carry out its mandate? Does Nedlac sufficiently publicise its successes? Should it still be located in the Ministry of Labour or should it now be moved to the office of the Presidency or Deputy-Presidency?

In addressing these questions the Nedlac review will hopefully identify the bottlenecks and constraints in the institution's functioning that often generate frustration within and as between its main stakeholders. Nothing has gone wrong in Nedlac that cannot be repaired by creative thinking in organisational design and management. But there is no doubt that key changes are needed if Nedlac is to meet its mandate and still remain relevant to the national agenda. In particular, ways must be sought to ensure that Nedlac becomes an active driver of effective dialogue, rather than just its passive custodian. While an institution like Nedlac can never act independently of its stakeholders, it can more forcefully and speedily drive processes forward to successful conclusions.

With an extensive assessment of the role and impact of institutionalised social dialogue in South Africa in the offing, I would like to conclude with only four key thoughts:-

Firstly promotion of the valid reasons that prompted the creation of Nedlac also made for excessive expectations as to what social dialogue could achieve in South Africa in the short term. Given the bitter legacy of apartheid it was too optimistic to expect significant levels of trust to be established more or less overnight. In time, the expectations, faiths and hopes of social dialogue have needed more realism. The intense enthusiasm which had greeted the advent of democracy could not last as the real problems of governance 
crowded in. Social dialogue, as important as it is as a mechanism to manage change, can in a mere eleven years only do so much to repair decades and even centuries of mistrust and suspicion. To that extent, criticisms that Nedlac is failing to achieve its goals are based on unrealistic hopes - or wishful thinking - about how South Africa can best respond to the challenges of transformation and globalisation. In addition, root causes of the congestion of work that has often accumulated in the Nedlac pipeline are also to be found not only in faulty institutional machinery but also in the magnitude and complexity of the tasks which government feels itself compelled to undertake. The logistical problems in Nedlac are a microcosm of the more generalised lack of capacity experienced elsewhere - which are also compounded by the emergence of other overlapping 'consultative' structures.

Secondly, some organisation theory has it that institutions are designed according to their constituents' basic needs at the time of their formation. These requirements will change over time and generate increasing pressure for adaptation to any changes in the overall environment and to effect improvements. In doing this institutional assessment there is probably a need to think of the Nedlac process in terms of trade-offs between various performance criteria, rather than as a unique institutional solution that maximises social welfare. Seen in this context, social dialogue is a renewal resource. A renewed vision of institutionalised social dialogue in South Africa is possible, if we want to retain Nedlac.

The third key thought revolves around the changing relationship between policymaking, implementation and monitoring in South Africa. Most of the 'big' policy issues in South Africa should — for good or ill — have now been settled, which is markedly different from the situation pertaining in the early years of Nedlac. Agreements at Nedlac level, especially on specific programmes and projects such as those in the 2003 Growth and Development Summit (GDS), mean little if they are not implemented properly. South Africa has reached a stage where, in several areas of policy, implementation and monitoring are now critical requirements for effective delivery. A Nedlac reassessment can help us to see where the institution should fit into this new 'fusion' of policymaking, implementation and monitoring in South Africa. It is never easy to find the institutional setup to meet this challenge. The social partners - labour and business - nonetheless have a key role in helping to identify and mobilise the appropriate capacity and expertise. Both the GDS - and more recently the Accelerated and Shared Growth Initiative for South Africa (ASGI-SA) - have identified serious weaknesses in this regard, especially at the local government level. Nedlac needs to be refocused to accommodate this new dimension within an appropriate institutional design.

Finally, we are still in a situation in South Africa where a number of policy decisions are often made in great ignorance of the consequences. Hence the policy choices are not always as well-informed as they should be, especially if we want South Africa to be globally competitive. Our minds, and policies, are still too often dominated by cliches; we tend to judge by categories, instead of by substantiated implications. If, therefore, an effective consultation process - by emphasising the results of action, rather than action considered intrinsically — can do something to focus our assessments on real issues and perceptions, we could hope that at least some of our differences may dissolve. Properly structured - and underpinned by good research — institutionalised social dialogue is a valuable mechanism to this end. In any case, is there a plausible alternative in South African circumstances? 


\section{CONCLUSION}

The fundamental challenge remains how to reconcile a dynamic economy — and the liberating effects of individual freedom - with the goals of an inclusive society even at the cost of some disturbance to a few cherished ideological shibboleths. The search for the right balance is not yet over. This is not a new debate and we are not the first generation or country to discuss it. Nor will we be the last to design institutions that can help us to sensibly manage these dilemmas and trade-offs in the years ahead, given the socio-economic challenges that still remain for South Africa. There is a strong perception that investment in social capital in South Africa is still lagging. Although social dialogue may have widened, the extent to which it has deepened'is still an open question. While there are issues on which economic ideology and race will continue to divide us, we can address common challenges in ways which do not force us to pay an even higher price for our divisions than we have already done. Effective social dialogue remains one significant way to help bridge these divides and to make progress on crucial issues that still matter to the future of South Africa.

\section{ANNEXURE 1}

Founding declaration of Nedlac

Growth, equity and participation

(1) The democratic election of 1994 opened a new era for South Africa. It was the decisive step in the transition to democracy. Now our country must meet the challenges of social development and economic growth.

(2) South Africa is a land rich in resources, with a strong and diversified economy. It has a people eager to make the democracy work. It has a well-developed physical and financial infrastructure, such as transport, telecommunications and the banking system.

(3) South Africa is also characterised by severe inequality in incomes, skills, economic power, ownership, and a skewed pattern of social development. This, together with largescale unemployment and inadequate economic performance, has created major problems in our society.

(4) Government, organised labour, organised business and community-based organisations need to develop and strengthen cooperative mechanisms to address the challenges facing our new democracy. Our three defining challenges are:

(i) Sustainable economic growth - to facilitate wealth creation; as a means of financing social programmes; as a spur to attracting investment; and as the key way of absorbing many more people into well-paying jobs

(it) Greater social equity — both at the workplace and in the communities — to ensure that the large-scale inequalities are adequately addressed, and that society provides, at least, for all the basic needs of its people

(Hi) Increased participation — by all major stakeholders, in economic decision-making, at national, company and shop-floor level — to foster cooperation in the production of wealth, and its equitable distribution

(iv) Meeting these challenges is critical to the success of the Reconstruction and Development Programme

(v) The National Economic Development and Labour Council (Nedlac) is the vehicle by which government, labour, business and community organisations will seek to cooperate, 
through problem-solving and negotiation, on economic, labour and development issues, and related challenges facing the country

Nedlac will conduct its work in four broad areas, covering:

(i) public finance and monetary policy

(it) labour market policy

(Hi) trade and industrial policy

(iv) development policy

(i) Nedlac established in law through the National Economic Development and Labour

Council Act, Act 35 of 1994, and will operate in terms of its own constitution.
Minister Tito Mboweni on Mr John Gomomo on
behalf of Government behalf of COSATU, NACTU and FEDSAL
Mr David Brink on behalf of Organised Business

Saturday 18 February 1995

Midrand, Gauteng

ANNEXURE 2

Organisational structure of Nedlac

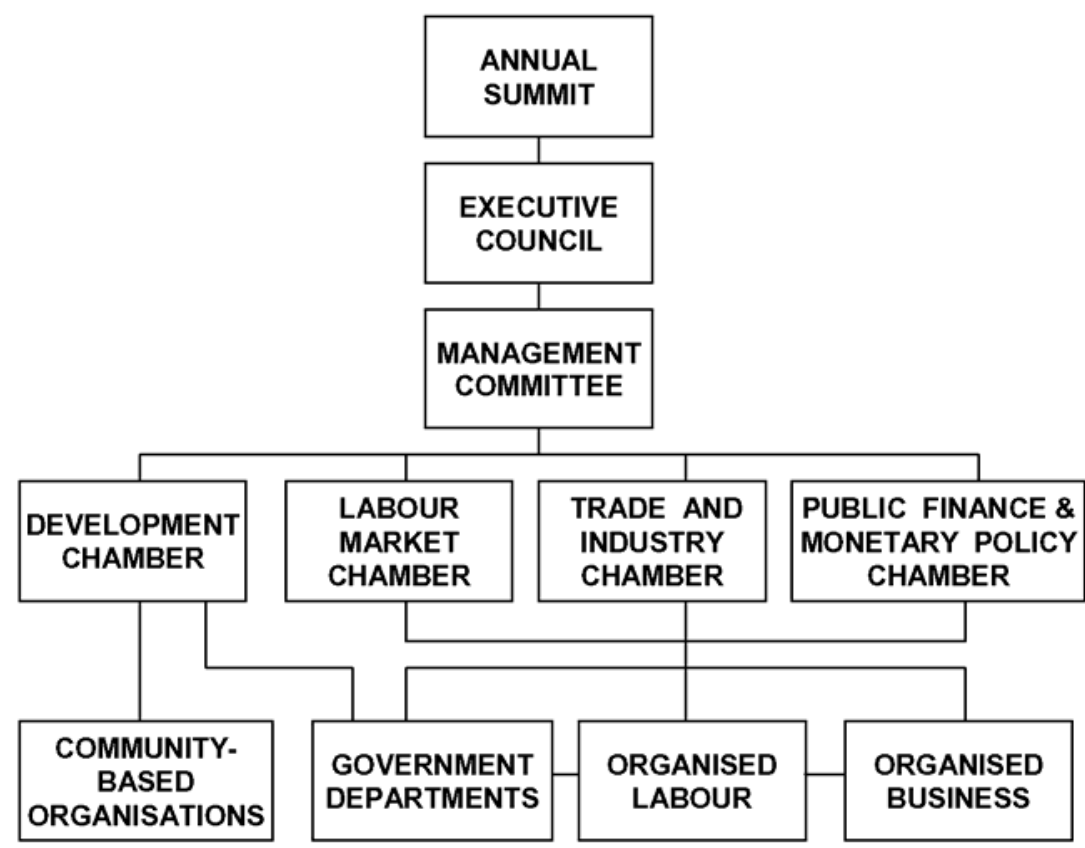

SELECTED BIBLIOGRAPHY

ADAM, H. (1999). Corporatism as minority veto under ANC hegemony in South Africa. The Awkward Embrace, (pp. 261-280), Tafelberg Publishers. 
ADLER, G. (1998). Engaging the state and capital and the deepening of democracy in South Africa, NALEDI, Johannesburg. and WEBSTER, E. (2000). 'Introduction' to Trade Unions and Democratisation in South Africa, 1985-1997, London.

- and - (1997). Bargained Liberalisation: The Labour Movement, Policy-Making and Transition in Zambia and South Africa, Seminar Paper presented to the Institute for Advanced Social Research, University of the Witwatersrand. ALENCE, R. (1997). The economic policy-making process in South Africa: report on a survey of an informed panel, HSRC, Pretoria.

ANSTEY, M. (1999). Managing Change, Negotiating Conflict, Juta.

ARROW, K. J. (1999). Observations on Social Capital, in Dasgupta and Serageldin, Op cit, pp. 3-5.

BASKIN, J. (ed) (1996). Against the Current, Ravan Press, Randburg.

BERNSTEIN, A. (ed), (1999). Policy-making in a New Democracy (esp. Section 1), Centre for Development and Enterprise, Johannesburg.

BETHLEHEM, R. (1997). Erasing NEDLAC won't rub out any problems, Business Report, 12 September.

BLUNKeTT, D. (2001). Politics and Progress: Reviewing Democracy and Civil Society, Politicos, London.

BOURDIEU, P. (1986). Forms of Capital, in handbook of Theory and Research for the sociology of Education, John C Richardson, Ed, Westport, CT, Greenwood Press, pp. 241-260.

BUSINESS UNITY SOUTH AFRICA (BUSA). (2006). BUSA Recommendations on Social Dialogue and NEDLAC, Submission to NEDLAC Review Process.

CHEADLE, H. (2006). Regulated Flexibility and Small Business - revisiting the LRA and the BCEA, (ASGISA).

CHWE, M. S.-Y. (1999). Structure and Strategy in Collective Action, Amer. J. Sociology 105, pp. 128-156.

COLEMAN, J. S. (1988). Social Capital in the Creation of Human Capital, Amer. J. Sociology 94, pp. S95-S120. Reprinted in Dasgupta and Serageldin, eds. op. cit. pp. 13-39.

COSTA, D. L. and KAHN, M. E. (2001). Understanding the Decline in Social Capital, NBER working paper 8285. http://www.nber,org/papers/w8295.

COSATU - various policy documents.

DASGUPTA, P. (1999). Economic Progress and the Idea of Social Capital, in Dasgupta and Serageldin, eds. op. cit. pp. $325-424$.

- and SERAGELDIN, I. eds. (1999). Social Capital: A Multifaceted Perspective, Washington, DC: World Bank. DAVIS, L. and NORTH, D. (1971). Institutional Change and American Economic Growth, NY: Cambridge U. Press. DE BONO, E. (1986). Conflicts: A Better Way to Resolve Them, Penguin.

DEXTER, P. (2000). Labour Market Policy by Consensus? The NEDLAC Experience, Innes Labour Brief, Vol. 12, No. 2, December.

DOUWES, D. L., METTON, E. and BUTCHER, C. (1998). Working Document for the social dialogue section of the NEDLAC annual report, Industrial Democracy Programme. University of the Witwatersrand, Johannesburg.

DURLAUF, S. (1999). The Case 'Against' Social Capital, Focus 20, pp. 1-5.

FEDDERKE, J. W. (1999). So Weber was right all along.... Theoria.

FEINSTEIN, C. (2005). An Economic History of South Africa: Conquest, Discrimination and Development, Oxford University Press.

FOLEY, M. and EDWARDS, B. (1996). The Paradox of Civil Society, Journal of Democracy, Vol. 7, No. 3.

FOLEY, M. W. and Edwards, B. (1999). Is It Time to Disinvest in Social Capital? J Public Pol. 19:2, pp. 141-173.

FRANKEL, S. H. (1959). The Economic Impact of Under-developed Societies, Oxford.

FUKUYAMA, F. (1995). Trust: The Social Virtues and the Creation of Prosperity, Hamish Hamilton, London. (1999). The Great Disruption - Human Nature and the Reconstitution of Social Order, Profile Books, London. (2000). Social Capital and Civil Society, IMF Working Paper, WP/00/74.

GLAESER, E., LAIBSON, D. and SACERDOTE, B. (2000). The Economic Approach to Social Capital, NBER working paper 7728. http://papers.nber.org/papers/W7728.

GOSTNER, K. and JOFFE, A. (1997). Negotiating the future: Labour's role at NEDLAC, NALEDI, Johannesburg.

GOSTNER, K. February (2000). Social Dialogue in South Africa, NEDLAC Report.

HEFNER, R. W. (1998). Civil Society and Democracy, Society, March-April.

HELLIWELL, J. F. and Putnam, R. D. (1995). Economic Growth and Social Capital in Italy, Eastern Econ J 21. Reprinted in Dasgupta and Serageldin, eds. op. cit. pp. 253-268.

HIRSCH, A. (2005). Season of Hope: Economic Reform under Mandela and Mbeki, University of KZN / IDRC.

INTERNATIONAL LABOUR ORGANISATION (ILO) - various publications on tripartism and social dialogue, Geneva.

KNACK, S. and KEEFER, P. (1997). Does Social Capital Have an Economic Payoff? Quart. J. Econ 112, pp. 1251-1288. LABOUR MARKET COMMISSION. (1996) Report of the Commission to Investigate the Development of a Comprehensive Labour Market Policy, Government Printer.

LANDES, D. (1999). The Wealth and Poverty of Nations, Abacus.

LASH, S. (1985). The end of Neo-corporatism?: The Breakdown of Centralised Bargaining in Sweden, British Journal of Industrial Relations, July.

LIEBENBERG, I. (1997). Consolidation of Democracy in Africa: Impact on Civil Society, African Security Review, Vol. 6, No. 4.

LEWIS, D. (1998). Pacts and the Consolidation of South African Democracy, Politics of Economic Reform Conference, Cape Town.

LODGE, T. (1999). South African Politics since 1994, David Philip. 
MANDELA, N. 18 February (1995). Speech by President Nelson Mandela the launch of National Economic Development and Labour Council, Johannesburg.

MANSKI, C. (2000). Economic Analysis of Social Interactions, J. Econ. Perspect 14, pp. 115-136.

NAIDOO, J. (1997). Don't fracture the negotiating forum, Sunday Times, 21 September.

NAIDOO, R. (1997). Working Paper for UNIDO, NALEDI.

NARAYAN, D. and PRITCHETT, L. (1999). Social Capital: Evidence and Implications, in Dasgupta and Serageldin, eds. op. cit. pp. 269-295.

NEDLAC. (1995-2005). Annual Reports and other Nedlac documentation. (2005). The NEDLAC Experience: 10 years of Social Dialogue.

NORTON, D., ROSKAM, A. and TAYLOR, M. (2002). The Social Partners Strike a New Deal, SA Labour Bulletin, 26 (3). O'CONNELL, P., GASH, V. and O'DONNELL. (1999). Country Employment Policy Reviews: Ireland, Social Dialogue and Employment Successes, ILO: Geneva.

O’DONNELL, R. (1998). Ireland's Economic Transformation, Industrial Policy, European Integration and Social Partnership, No. 2, December.

O'DONNELL, P. et al. (1999). Social Dialogue and Employment Success - Ireland, ILO, March.

OLSON, M. Jr. (1996). Big Bills left on the Sidewalk; Why some Nations are Rich and Others Poor, Journal of Economic Perspectives - Vol. 10, No. 2 - Spring 3-21 pp.

OSTROM, E. (1990). Governing the Commons: The Evolution of Institutions for Collective Action, Cambridge: Cambridge U Press.

- (1999). Social Capitalism: A Fad or a Fundamental Concept, in Dasgupta and Serageldin, eds. op. cit. pp. 172-214. PARSONS, R. (1995). The Institutional Framework of Economic Policymaking in South Africa, Inaugural lecture to the University of Pretoria, 29 August.

- (1996). The NEDLAC Needle, Business Report, 24 May.

(1996). NEDLAC using 'Social Capital' for development, Business Day, 5 June.

(1997) NEDLAC must be seen to work to fulfil role in the economy, Sunday Argus (Finance), 7 September. - and VAN RENSBURG, B. (1998). The Role of the National Economic Development Labour Council in the Process of Policy Formation in the New South Africa, Unpublished paper for the Centre for Development and Enterprise.

- (1998). The case for NEDLAC, Finance Week, 14-20 May.

- (1999). The Mbeki Inheritance - South Africa's Economy 1990-2004, Ravan Press, Johannesburg.

- (2000). NEDLAC bas building to do, Business Report, 30 June.

- (2000). NEDLAC achieves progress on key issues, Business Report, 15 September. (2001). Steps towards social dialogue and the development of NEDLAC in a democratic South Africa 1979-2001, SA Journal of Economic History, Vol. 16, pp. 139-171. - (2002). Parsons' Perspective - Focus on the Economy, published by Jonathan Ball.

- (ed.) (2004). Manuel, Markets and Money - Essays in Appraisal, published by Double Storey Books (Juta).

- (2007). 'The role of social dialogue in policymaking in South Africa', chapter in the forthcoming publication South Africa: Economy and Policy, 1990-2000, Manchester University Press.

PITYANA, S. (1997). NEDLAC: Government by collective bargaining? New Nation, 23 May.

PRZEWORSKI, A., et al. (1995). Sustainable Democracy, Cambridge, Cambridge University Press.

PUTMAN, R. (1993). Making Democracy Work: Civil Traditions in Modern Italy, Princeton Press. (2000) Bowling Alone, Simon \& Schuster.

ROBERTSON, SIR DENNIS (1956). The Rôle of Persuasion in Economic Affairs, Economic Commentaries, Staples, p. 155.

ROSE, R. (1999). Getting Things Done in an Antimodern Society: Social Capital Networks in Russia, in Dasgupta and Serageldin, eds. op. cit. pp. 147-171.

ROSENTHAL, T. (1996). Focus on NEDLAC: Getting down to Business, South African Labour Bulletin, Vol. 20 (3) 44-49. SELLARS, C. (2000). Unemployment, Policy and Social Partnership, SAJE, September.

SEN, A. K. (1999). Development as Freedom, New York, Knopf.

SITAS, A. and JARVIS, D. (1998). Co-determination and transformation: co-option or alternative vision? NALEDI, Johannesburg.

SLABBERT, F. V. Z. (2006). The Other Side of History, Jonathan Ball.

SOBEL, J. (2002). Can we Trust Social Capital? Journal of Economic Literature, Vol. XL, pp. 130-154.

SOUTH AFRICA FOUNDATION. (1996). Growth for All: an economic strategy for South Africa, Johannesburg. STEYN, G. (2000). Social Dialogue is alive and well in South Africa, Business Day, 23 May.

STIGLITZ, J. E. (1999). Formal and Informal Institutions, in Dasgupta and Serageldin, eds. op. cit. pp. 59-68.

TREBILCOCK, A. et al, (1994). Towards Social Dialogue: Tripartite Co-operation in National Economic and Social Policy Making, Geneva: International Labour Office.

TURNER, A. (2001). Just Capital - the Liberal Economy, MacMillan.

TURNER, J. H. (1999). The Formation of Social Capital, in Dasgupta and Serageldin, eds. op. cit. pp. 94-146.

VISSER, J. (1998). Two Cheers for Corporatism, One for the Market: Industrials Relations, Wage Moderation and Job Growth in the Netherlands, Blackwell.

WALSH, B. (1996). Stabilisation and adjustment in a small open economy: Ireland 1979-1995, Oxford Review of Economic Policy, Autumn.

WEBSTER, E. and GOSTNER, K. October (1995). NEDLAC: building consensus in a new democratic order, Sociology of Work Unit: Johannesburg. 
openUP

(1995). NEDLAC: Corporatism of a Special Type, South African Labour Bulletin, Vol. 19 (2) pp. 25-29.

London.

and ADLER, G. (Eds), (1998). Trade Unions and Democratisation in South Africa, MacMillan, Johannesburg/

WIJFFELS, H. H. F. (2001). Social Dialogue in the Netherlands, IAESEC 7th Annual Conference, The Hague, July.

WILliAMSON, O. E. (1993). Calculativeness, Trust, and Economic Organization, J Law Econ 36, pp. 453-486.

WOOLCOCK, M. (1998). Social Capital and Economic Development, Theory and Society 27, pp. 151-208.

WORLD BANK. (2001). Povertynet: Topics relevant to Social Capital, New York, Oxford University Press.

YANNAKOUROU, M. (2001). The Rôle of Economic and Social Councils and Similar Institutions throughout the world, IAESEC, The Hague, July. 